Acta Technologica Agriculturae 3

Nitra, Slovaca Universitas Agriculturae Nitriae, 2015, pp. 92-96

\title{
EVALUATION OF SOIL PHYSICAL PROPERTIES IN SYSTEM WITH PERMANENT TRAFFIC LANES PRACTISED IN 10 HA FIELD
}

\author{
Dumitru GUTU, Josef HŮLA*, Milan KROULÍK \\ Czech University of Life Sciences Prague, Czech Republic
}

\begin{abstract}
The paper deals with basic soil physical properties as affected by wheel traffic. Agricultural land is, in varying degrees, exposed to the pressures exerted by running parts of tractors, harvesting machinery and transport equipment. Damaging the soil by compaction increases the energy efficiency, deteriorates the quality of tillage, may reduce crop yields and is associated with environmental risks that accompany water erosion. The selection of results from field trials demonstrates the positive effect of the reduction of level crossings on the results of physical and mechanical properties of the soil.
\end{abstract}

Keywords: soil compaction; controlled traffic farming; soil physical and mechanical properties

Contemporary farming systems in agriculture are associated with negative impacts on soil which damage both productive and non-productive functions of the soil. One of these effects is soil compaction. Soil compaction is one of the major problems facing modern agriculture. The overuse of machinery, intensive cropping, short crop rotations, intensive grazing and inappropriate soil management leads to compaction. Soil compaction occurs in a wide range of soils and climates (Hamza and Anderson, 2005; Batey, 2009; Antille et al., 2013). In addition to the adverse impact of soil compaction on crop yields, also environmental consequences are particularly serious. It is mainly related to the intensive exploitation of heavy agricultural machinery. The continuous increase in the weight of farm machinery and the necessity to use heavy machines in unfavourable soil conditions increases the potential for subsoil damage (Alakukku et al., 2003). Compaction occurs if the stress imposed by traffic causes damage to soil pores. Damage includes both the compression and shearing of the soil pore structure (Chamen et al., 2015). Traffic-induced soil compaction is known as the process induced by wheeling of mobile farming units in which soil particles are spatially rearranged, which leads to increasing of soil bulk density (Hamza and Anderson, 2005). Passes over fields are unavoidable in today's agriculture and the soil compacted by machinery tyres is not the only one problem for one year or even one season. Undesirable compaction and changed soil structure may be found even after several years (Radford et al., 2007). The extent of the soil compaction problem is a function of soil type and water content and further vehicle weight, speed, ground contact pressure and the number of passes, and their interactions with cropping frequency and farming practices (Ball and Ritchie, 1999; Chamen et al., 2003, 2015; Chan et al., 2006; Radford et al., 2007).

The use of GPS in common agricultural practice, especially for positioning in the field, has been a milestone for modern agriculture systems and precision farming which is based on precise operations (Sparovek and Schnug, 2001). Control traffic farming (CTF) with precisely set tyre tracks could be a tool for minimising of soil compaction risk, since CTF is based on maintaining the same wheel lanes for several years (Hadas et al., 1990; Raper, 2005).

The greatest benefits from the CTF system are obtained when all machinery, including the harvester, are matched to the same wheel base. The technical solution to having the same tyre or belt spacing on all machines in the field could be the main obstacle for common utilization of CTF. On the other hand, it is possible to use the CTF system without strictly following these conditions (Kroulík et al., 2011).

The main issue of this paper is the evidence of the possibility of organizing the controlled traffic of farm machinery on land and the impact on physical and mechanical properties of soil.

\section{Material and methods}

The measurements of soil properties were carried out in the Krinec locality - Central Bohemia (50 $13^{\prime} 50.82^{\prime \prime} \mathrm{N}$, $\left.15^{\circ} 06^{\prime} 9.65^{\prime \prime} \mathrm{E}\right)$, agricultural company ZAS Podchotuci, jointstock company, $200 \mathrm{~m}+$ MSL (mean sea level) and Leptosols soil type. Texture was described as loamy soil (clay content (g/kg) 383, C ox 3.8\%). Crop rotation takes around four years and comprises of two crops [e.g. pea (Pisum sativum L.) - winter wheat (Triticum aestivum) - winter wheat (T. aestivum) - pea (Pisum sativum L.)]. A field trial on a land size of 10 ha was established in spring 2010. The system with permanent driving tracks in the module of machines with a working width of $6 \mathrm{~m}$ has been applied on the plot for five years. The out track system (Figure 1) was used, similarly as in Galambošová et al. (2010). 


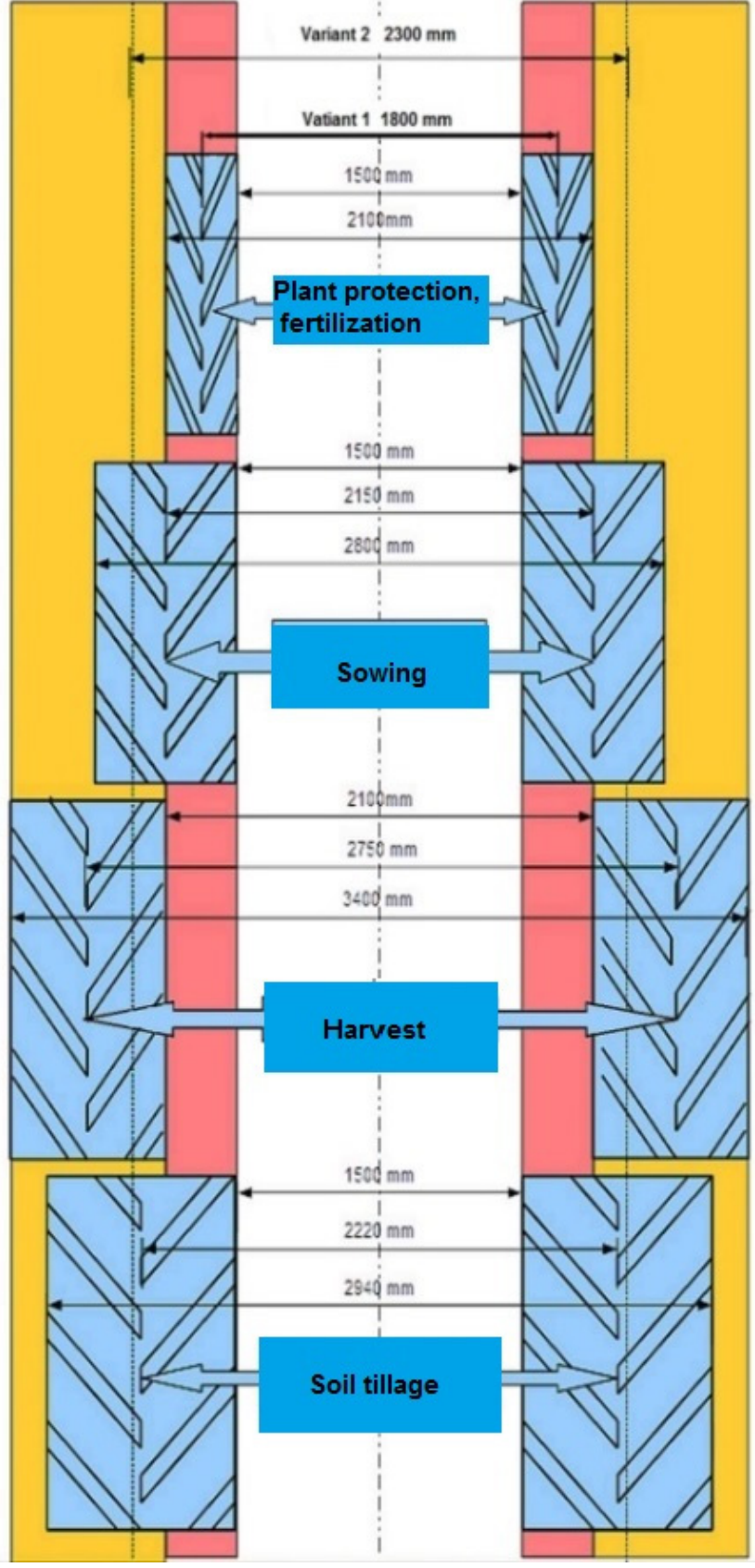

Figure 1 Wheel ruts of tractors and combine harvester after their concentration to permanent traffic lanes

$\square$ area with intense wheel ruts, $\square$ area with a low number of wheel ruts, $\square$ area with zero wheel ruts
A GPS satellite system with the RTK VRS correction signal was used for the navigation of machines during soil tillage, sowing, application of chemicals for plant protection, application of mineral fertilizers and during harvest. An assisted steering system AgGPS EZ-STEER Trimble has been used for machines steering (since 2012 upgrading to EZ-PILOT and Autopilot Trimble).

On the experimental field, the soil properties were evaluated in four variants of wheel effect: Variant 1 - Traffic lanes including application of chemicals for plant protection and mineral fertilizers (spraying rows); Variant 2 - Traffic lanes without application of chemicals for plant protection and mineral fertilizers (sown rows); Variant 3 - Outside the traffic lanes; Variant 4 - Random traffic. Random traffic was applied in the area of 3 ha within the experimental field.

During the soil tillage, trajectory rides of machines sets were shifted in navigation in the part of field with random passages (in the direction of other passages). This results in an increase of soil surface with passages by $32 \%$ during the season.

Table 1 and Figure 1 document the field operations and machines used for work operations.

Penetration resistance measurements were made at 0.04 $\mathrm{m}$ intervals, in the depth from $0.04 \mathrm{~m}$ to $0.40 \mathrm{~m}$, with a handpushed, recording penetrometer $\mathrm{PN}-10$ penetrologger (CULS Prague, Czech Republic). Penetration resistance measurements were repeated ten times. The penetrometer had a $30^{\circ}$ cone angle with an area of $1 \mathrm{~cm}^{2}$. Total soil porosity was evaluated by means of undisturbed soil samples taken into Kopecky's rings $\left(100 \mathrm{~cm}^{3}\right)$. The samples were processed in the standard way described by Valla et al. (2008). To measure the shear stress of soil, a CL-100 vane probe (Terratest) was used (Figure 2). The method is used for determining the cohesion of the soil. The lamellas head device is pressed into the soil after cutting the soil to a plane. After inserting fins into the soil, the lamellas head rotates with a constant velocity. After overcoming limits, the soil between the lamellas and the soil layer is separated. Detected scale reading on the device is expressed as shear stress. The same method of measuring was used for measuring the shearing stress and strength of clods after soil treatment.

STATISTICA 12 with the analysis tool ANOVA was used for statistical evaluation of results, specifically the Tukey's HSD test.

Table 1 Field operations and machines

\begin{tabular}{|l||c|c|c|c|}
\hline \multicolumn{1}{|l||}{ Field operation } & Machines & Working width, $\mathbf{m}$ & Distance of tracks, mm & Tyre width, mm \\
\hline Shallow loosening & CASE 335 + FARMET Hurikan 600 & 6 & 2220 & $720 \times 2$ \\
\hline Medium deep loosening & CASE 335 + Simba SLD 600 & 6 & 2220 & $720 \times 2$ \\
\hline Sowing & $\begin{array}{c}\text { NEW HOLLAND 7060 + VäderSTAD } \\
\text { Rapid 600P }\end{array}$ & 6 & 2150 & $500 \times 2$ \\
\hline Mineral fertilizers application & ZETOR 10145 + AMAZONE 1000 & 18 & 1800 & $300 \times 2$ \\
\hline Pesticide application & CASE JX 1100U + AGRIO NAPA 18 & 18 & 1800 & $320 \times 2$ \\
\hline Harvest & CLAAS Lexion 460 & 6 & 2750 & $650 \times 2$ \\
\hline
\end{tabular}



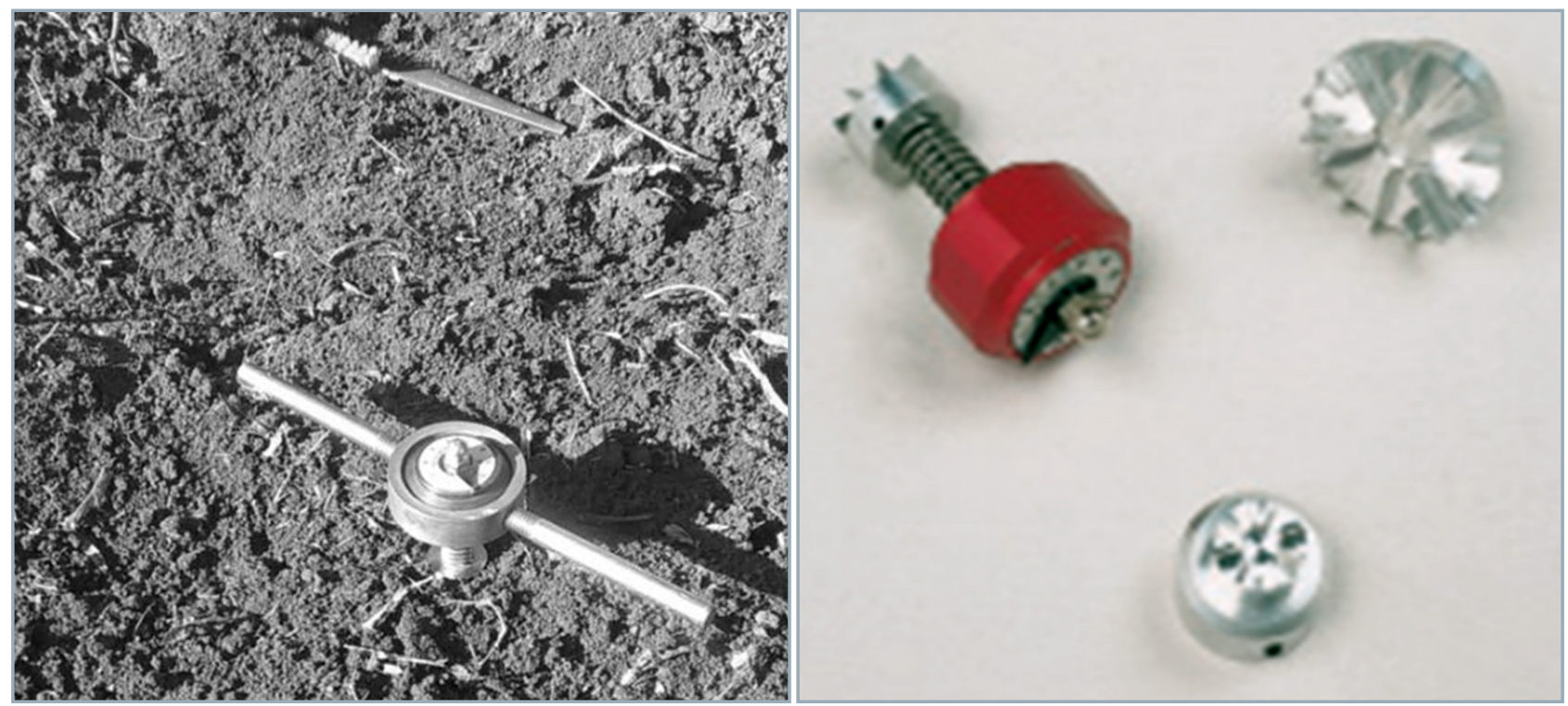

Figure 2

CL-100 vane probe for measuring of shear stress

\section{Results and discussion}

Figure 3 illustrates the values of penetration resistance in the topsoil in spring ( $6^{\text {th }}$ April 2013 - the fourth year of the field experiment establishment). Average soil moisture content in the depth of $0.00-0.40 \mathrm{~m}$ was 26.1 (weight \%). As expected, the lowest values of penetration resistance were found in variant 3 (outside the traffic lanes). A significant increase in penetration resistance was observed in the upper layer of soil in variant 1 (spraying rows). Similar results by Radford et al. (2007) observed significant differences $(p<0.001)$ in soil cone index obtained between the wheeled and non-wheeled soils. The results have confirmed that the cone index values of non-compacted soil are significantly lower than in the case of low traffic or conventional tillage system to a depth of $0.24 \mathrm{~m}$, while at greater depths significant differences were not observed.

Figure 4 shows the values of total soil porosity after soil samples were taken on $2^{\text {nd }}$ July 2013. At a depth of $0.15-0.20 \mathrm{~mm}$, the highest soil porosity was recorded in variant 3 (outside the traffic lanes). The values of soil porosity were lowest in variant 1 with the highest intensity of wheel traffic.

The mechanical properties of the soil are expressed by soil shear stress. Figure 5 shows that the values of shear stress in the surface layer of soil in

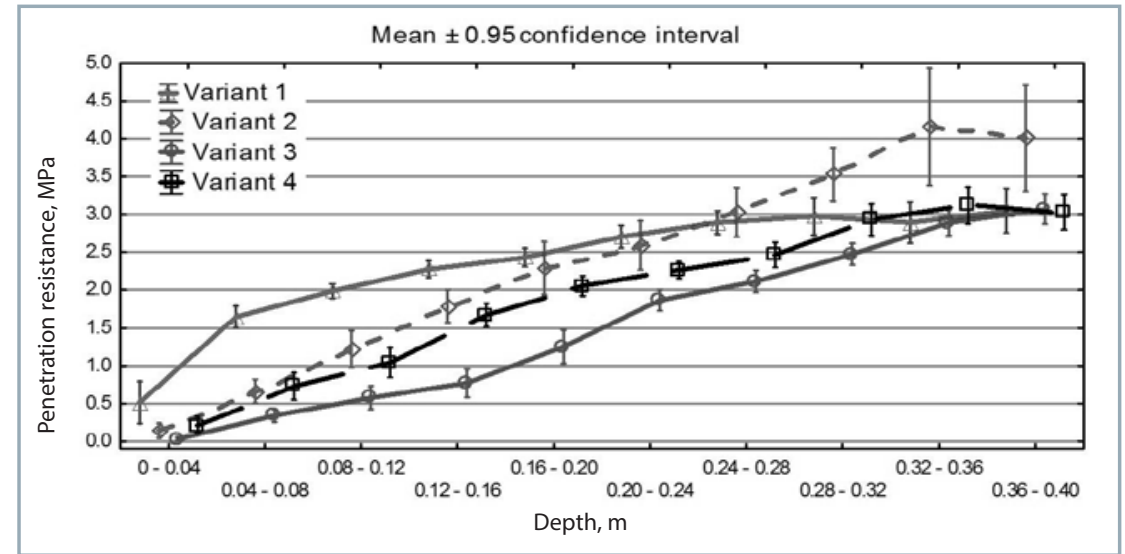

Figure 3 Penetration resistances in spring ( $6^{\text {th }}$ April 2013)

Error bars indicate \pm 0.95 confidence level

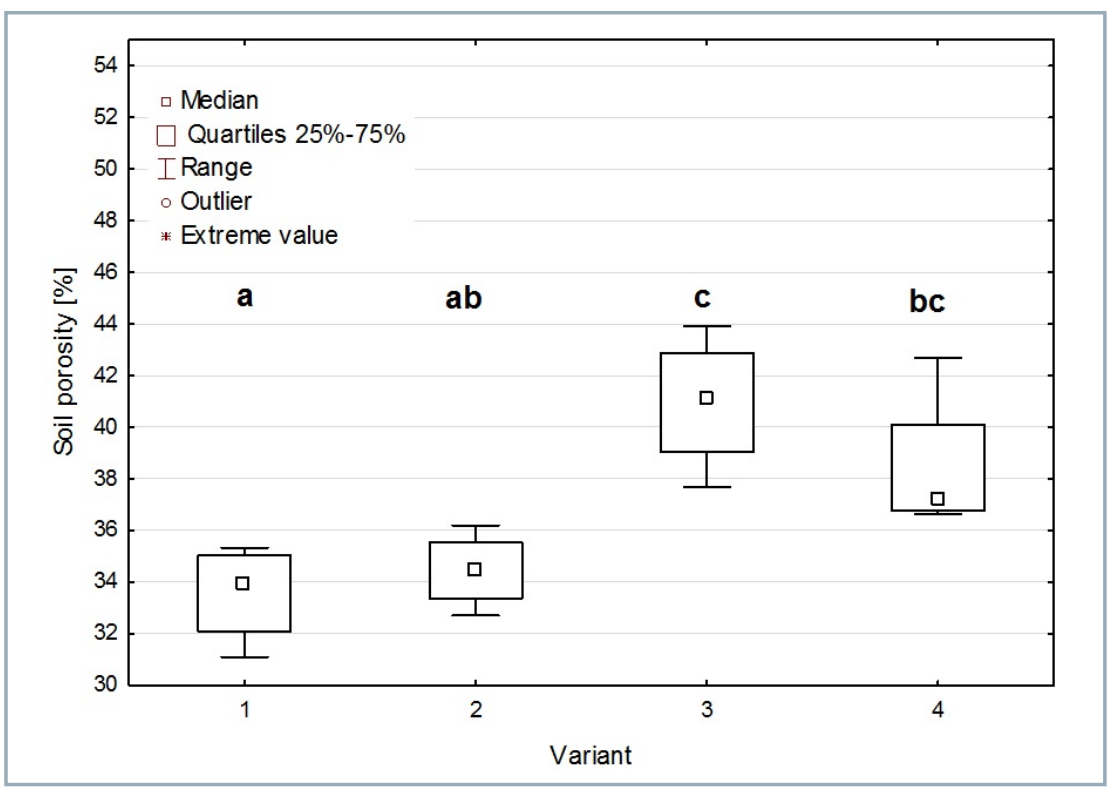

Figure 4 Soil porosity at a depth of $0.15-0.20 \mathrm{~m}$ (2 $2^{\text {nd }}$ July 2013)

Significant differences are indicated by different letters $(a, b, c)$ 


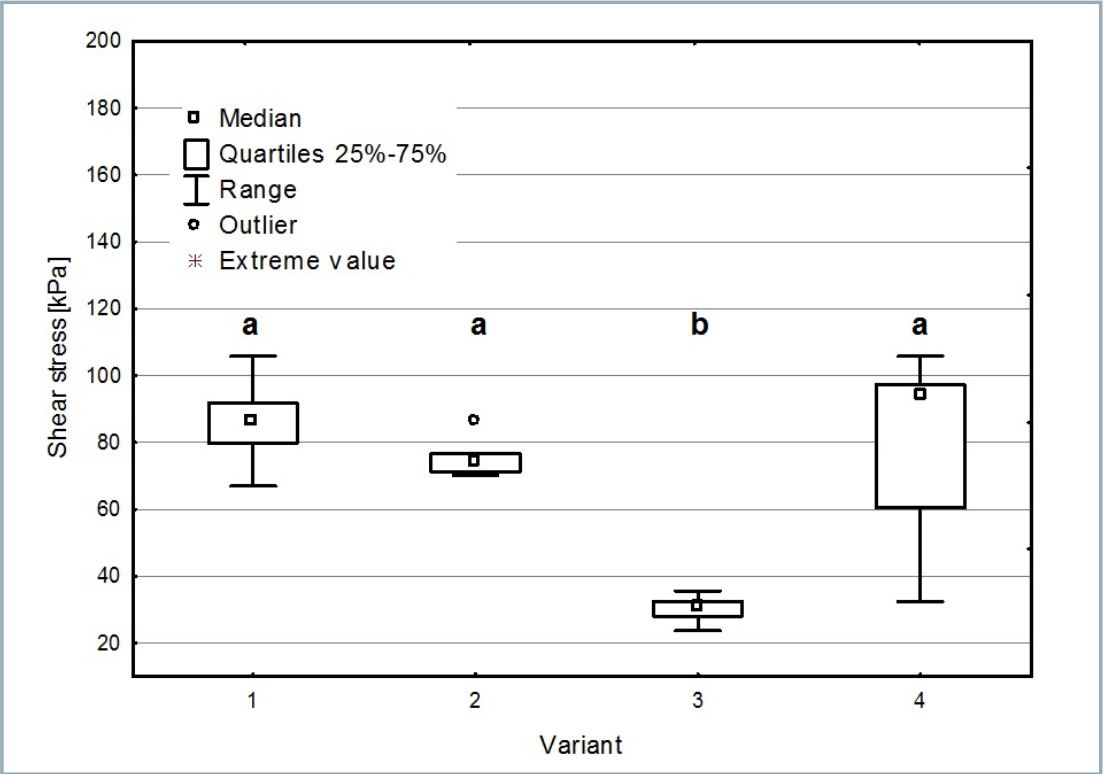

Figure 5 Shear stress of soil (depth $0.05 \mathrm{~m}$ ) in summer ( $2^{\text {nd }}$ July 2013) - average soil moisture content was 19.6 (weight \%)

Significant differences are indicated by different letters $(a, b)$

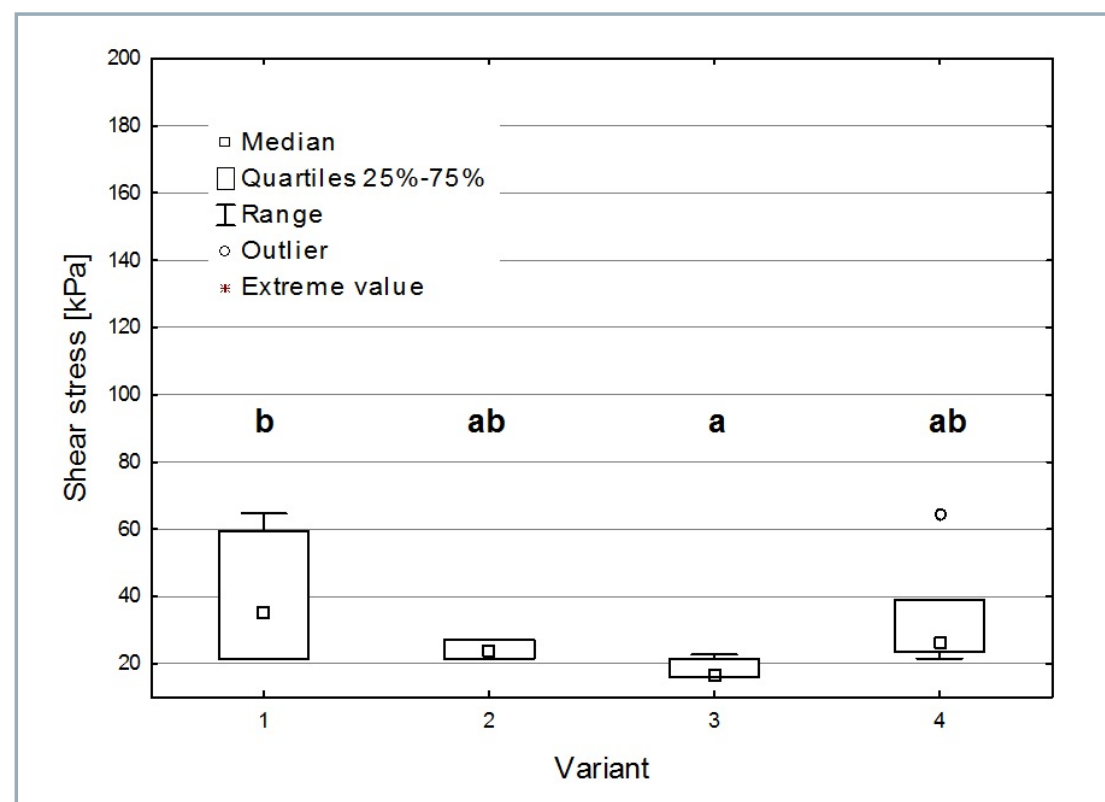

Figure 6 Shear stress of soil (depth $0.05 \mathrm{~m}$ ) in autumn (31 $1^{\text {st }}$ October 2013) average soil moisture content 18.6 (weight \%)

Significant differences are indicated by different letters $(a, b)$

variant 4 (random traffic) in summer are comparable with the values for variants 1 and 2 and were statistically significant, higher than in variant 3.

The clods of shear stress after soil tillage in autumn did not show significant statistical differences. These are shown in Figure 6.

During field trafficking, vertical and horizontal stress components as well as shear forces in the soil are caused by the profiled, moving and deflecting tyre (Alakukku et al., 2003). Compaction reducing rolling resistance, which is not contrary with the results of other authors (Keller and Arvidsson, 2004; Kovaříček et al., 2014; Defossez and Richard, 2002).

\section{Conclusion}

The results of the field experiment showed favourable soil physical properties outside the traffic lanes. On the part of the experimental field with random traffic, the physical and mechanical properties of soil were often similar to those in places of permanent traffic lanes. The area without wheel tracks accounted for $68 \%$ of the area of the field when the working width module of $6 \mathrm{~m}$ was used on the experimental land.

On the basis of current knowledge from the pilot field trial on the plot of 10 ha with the module working width of $6 \mathrm{~m}$, it can be summarized that the system of controlled trafficking is workable in operating conditions. The conditions are: the very good facilities of agricultural machinery of the company and technological discipline.

\section{Acknowledgment}

Supported by the Ministry of Agriculture of the Czech Republic Project QJ1520028

\section{References}

ALAKUKKU, L. - WEISSKOPF, P. - CHAMEN, W. C. T. - TIJINK, F. G. J. - VAN DER LINDEN, J. P. - PIRES, S. - SOMMER, C. - SPOOR, G. 2003. Prevention strategies for field trafficinduced subsoil compaction: a review. Part 1. Machine/soil interactions. In Soil and Tillage Research, vol. 73, no. 1-2, pp. 145-160.

ANTILLE, D. L. - ANSORGE, D. - DRESSER, M. L. - GODWIN, R. J. 2013. Soil displacement and soil bulk density changes as affected by tire size. In Transactions of the ASABE, vol. 56, no. 5, pp. 1683-1693.

BALL, B. C. - RITCHIE, R. M. 1999. Soil and residue management effects on arable cropping conditions and nitrous oxide fluxes under controlled traffic in Scotland 1. Soil and crop responses. In Soil and Tillage Research, vol. 52, no. 3-4, pp. 177-189.

BATEY, T. 2009. Soil compaction and soil management - a review. In Soil Use and Management, vol. 25, no. 4, pp. 335-345.

DEFOSSEZ, P. - RICHARD, G. 2002. Models of soil compaction due to traffic and their evaluation. In Soil and Tillage Research, vol. 67 , no. 1, pp. 41-64. 
GALAMBOŠOVÁ, J. - RATAJ, V. - MACÁK, M. - ŽITŇÁK, M. NOZDROVICKÝ, L. 2010. Controlled traffic farming and minimum tillage: results of initial experiments and layout of a longterm experiment. In XVII ${ }^{\text {th }}$ World Congress of the International Commission of Agricultural and Biosystems Engineering (CIGR). Retrieved from: https://www.bioeng.ca/publications/meetings-ap ers? sobi2Task=sobi2Details\&sobi2ld $=494$

HAMZA, M. A. - ANDERSON, W. K. 2005. Soil compaction in cropping systems - a review of the nature, causes and possible solutions. In Soil and Tillage Research, vol. 82, no. 2, pp. 121-145.

HADAS, A. - SHMULEVICH, I. - HADAS, O. - WOLF, D. 1990. Forage wheat yields as affected by compaction and conventional vs. wide frame tractor traffic patterns. In Transactions of the ASABE, vol. 33, no. 1, pp. 79-85.

CHAMEN, T. - ALAKUKKU, L. - PIRES, S. - SOMMER, C. - SPOOR, G. TIJINK, F. et al. 2003. Prevention strategies for field traffic-induced subsoil compaction: A review. Part 2. Equipment and field practices. In Soil and Tillage Research, vol. 73, no. 1-2, pp. 161-174.

CHAMEN, W. C. T. - MOXEY, A. P. - TOWERS, W. - BALANA, B. HALLETT, P. D. 2015. Mitigating arable soil compaction: A review and analysis of available cost and benefit data. In Soil and Tillage Research, vol. 146, part A, March 2015, pp. 10-25.

CHAN, K. Y. - OATES, A. - SWAN, A. D. - HAYES, R. C. - DEAR, B. S. PEOPLES, M. B. 2006. Agronomic consequences of tractor wheel compaction on a clay soil. In Soil and Tillage Research, vol. 89, no. 1, pp. 13-21.
KELLER, T. - ARVIDSSON, J. 2004. Technical solutions to reduce the risk of subsoil compaction: effects of dual wheels, tandem wheels and tyre inflation pressure on stress propagation in soil. In Soil and Tillage Research, vol. 79, no. 2, pp. 191-205.

KOVAŘ́lČEK, P. - HŮLA, J. - ABRHAM, Z. - VLÁŠKOVÁ, M. 2014. Management systems in order to reduce soil compaction and increase soil permeability for water. Applied certified methodology. RIAE Prague. 40 pp. (in Czech).

KROULÍK, M. - KVÍZ, Z. - KUMHÁLA, F. - HŮLA, J. - LOCH, T. 2011. Procedures of soil farming allowing reduction of compaction. In Precision Agriculture, vol. 12, no. 3, pp. 317-333.

RADFORD, B. J. - YULE, D. F. - MCGARRY, D. - PLAYFORD, C. 2007. Amelioration of soil compaction can take 5 years on a Vertisol under no till in the semi-arid subtropics. In Soil and Tillage Research, vol. 97, no. 2, pp. 249-255.

RAPER, R. L. 2005. Agricultural traffic impacts on soil. In Journal of Terramechanics, vol. 42, no. 3-4, pp. 259-280.

SPAROVEK, G. - SCHNUG, E. 2001. Soil tillage and precision agriculture: a theoretical case study for soil erosion control in Brazilian sugar cane production. In Soil and Tillage Research, vol. 61, no. 1-2, pp. 47-54.

VALLA, M. - KOZÁK, J. - NĚMEČEK, J. - MATULA, S. - BORU゚VKA, L. DRÁBEK, O. 2008. Pedological practicum. CULS Prague. 151 pp. (in Czech). 